\title{
Vocal Imitation in 3-Month-Old Infants : What is the Releasing Stimulus?
}

R. Lebib and P.-M. Baudonnière

\section{(2) OpenEdition}

1 Journals

Electronic version

URL: http://journals.openedition.org/cpl/246

DOI: $10.4000 / \mathrm{cpl} .246$

ISSN: $1379-6100$

Publisher

Centre PsyCLÉ

Printed version

Date of publication: 1 August 2000

\section{Electronic reference}

R. Lebib and P.-M. Baudonnière, « Vocal Imitation in 3-Month-Old Infants : What is the Releasing Stimulus ? », Current psychology letters [Online], 2000/2, 2 | 2000, Online since 17 September 2003 connection on 08 September 2020. URL : http://journals.openedition.org/cpl/246 ; DOI : https:// doi.org/10.4000/cpl.246

This text was automatically generated on 8 September 2020

(C) All rights reserved 
Vocal Imitation in 3-Month-Old Infants : What is the Releasing Stimulus?

R. Lebib and P.-M. Baudonnière 